\title{
De novo assembly and comparative transcriptome analysis revealed the genes that were potentially involved in defensive terpenoids emission in the wheat against the wheat aphid Sitobion avenae (Fabricius)
}

Research article

Keywords:

Posted Date: November 2nd, 2021

DOI: https://doi.org/10.21203/rs.2.15301/v3

License: (c) (i) This work is licensed under a Creative Commons Attribution 4.0 International License. Read Full License 


\section{Abstract}

The full text of this preprint has been withdrawn by the authors due to author disagreement with the posting of the preprint. Therefore, the authors do not wish this work to be cited as a reference. Questions should be directed to the corresponding author.

\section{Full Text}

The authors have withdrawn this preprint from Research Square. 